\title{
キリマンヂャロ山南麓の地下水
}

\author{
磯崎義正 $*$ ·外村昭久 $* * \cdot$ 光永忠生 $* *$ \\ 成田金蔵 $* *$ 田村文雄 $* *$. 東郎昭彦*** \\ 早坂和夫 $* * *$. 石井正克 $* * * *$
}

\section{Hydro-Geology of The South Foot of Mt. Kilimanjaro, in Tanzania}

\author{
Yoshimasa Isozaki, Akihisa Tonomura, \\ Tadao Mitsunaga, Kinzo, Narita, \\ Fumio Tamura, Akihiko Tōgo, \\ Kazuo Hayasak and Masakatsu Ishi
}

\begin{abstract}
This Areai, as shown in Fig. 3, has a basin structure, surrounded by faults or Precambrian basement rocks. The basin is fflled by alluvium deposits chiefly composed of sands, gravels, clays and calcareous deposits, with some amounts of lavas and pyroclastic rocks originated from Kilimanjaro Volcan. These deposits which are roughly estimated at more than $130 \mathrm{~m}$ in thickness in the south and seem to become thicker toward north are major aquifers in this area.

As shown in Fig. 9 the total quantity of water recharged in the Kahe-Miwaleni groundwater basin is estimated to be $300,000,000 \mathrm{~m}^{3} /$ year and the quantity of water consumed by surface runoff (mainly from the Miwaleni Spring) and pumping works is estimated $110,000,000 \mathrm{~m}^{3} /$ year. About half the quantity of recharge may be regarded as the object of the future groundwater exploitation. However, it is still dangerous to think that all of $190,000,000 \mathrm{~m}^{3} /$ year can be expoited in future. It is technically impossible to pump out all the potential quantity due to hydrogeological restrictions and power limit of the pumping facilities. The quantity of water that can be practically drawn up should be estimated at most $50,000,000 \mathrm{~m}^{3} / \mathrm{year}$, less than half the potential quantity.
\end{abstract}

\section{1. まえがき}

Mts. Kilimanjaro (5,895 m) は東部 Africa, Tanzania 国の北東縁にあり，Kenya 国に跨がっている。有名な African Great Rift Valley は東部 Africa 南北に縦貫 する断層陷没帯であるが，その東縁にあたる Kilimanjaro 火山は，この East African Rifts の活動と密接な関係が あることが知られている (R. Girdler, 1972)。

Kilimanjaro 火山南麓に拡がる広大な裾野は, 熱帯圈と 乙ては気象水文条件に恵宋れ, 古く加ら開発され人口密 度も高い。しかしながら, さらに南方に拡がる Pangani 川流域の低地は, 熱帯圈特有の乾燥気候と雨期の出水の

\footnotetext{
* 農林省関東農政局, ** 日本技術開発 K.K.

****リマンヂャロ州農業開発プロジェクトチーム

*****国際協力事業団
}

ために, Steppe や Swamp として殆えど未開発のままに 残されている。筆者等の調査の主目的は, このような地 域の水資源としての地下水開発の可能性を知り, 農業開 発計画策定の基礎資料とすることであった。

当地域の地下水に関するこれまでの調査研究も決して 少くはない。Tanzania 在住 30 年という経歴をもつオラ ンダの Engineering Geologist, M. Coster は, Tanzania 全体の地下水事情をまとめている (M. Coster, 1960)。 Coster はこの著書の中で，すでに Kilimanjaro 火山山麓 の地下水にもふれており，既設井の揚水量や水質につい て記述している。その後, 1960 年代の初めには盛んに 1/12.5 万地質図幅が Geological Survey of Tanzania か ら発刊されているが，その中に地下水や井戸に関する記 載が散見される。とくに Kilimanjaro 図幅の説明書には 同山麓一带の水理地質の説明がのっており, 地下水の賦 
存機構や井戸の揚水実績についてふれている(Geological Survey of Tanzania, 1965)。また，同じ頃には南 麓一帯について，地下水を対象とした調查が行なわれる よにうなり，それらの成果が Whittingham (1963) や Ramsay (1965) などの報告にまとめられている。これら の報告はいずれも地形地質と既設井の実績をもとにし て，地下水の賦存機構や带水層についてふれているのみ で, 帯水層の拡がりや厚さ，その水理学的性質および水 収支などの地下水の量的な評価は加えられていない。

この報文は地表地質調查, 電気探査, 水文気象調査, 揚水試験，資料収集などによって明らかにされた本地域 の水理地質構造, 地下水賦存㥞式, 帯水層の水理学的性 質，地下水盆内の水収支などについてとりまとめたもの である。

なお，調查は1976 年1 2月に行なわれたが，調查 期間が制約されており調査手段, 調查機器について子充 分な対応ができえなかったため, 精度的に不満な点や行 き届いていない部分などもあり，残された問題点も少な くない。しかしながら赤道地方の火山山棍の水理地質学 的特質について，その概要なりと理解いただければ幸い である。

本報文を⿱とめるにあたって，炎天下の悪条件にもか かわらず熱心に調査に協力していただいた現地在住専門

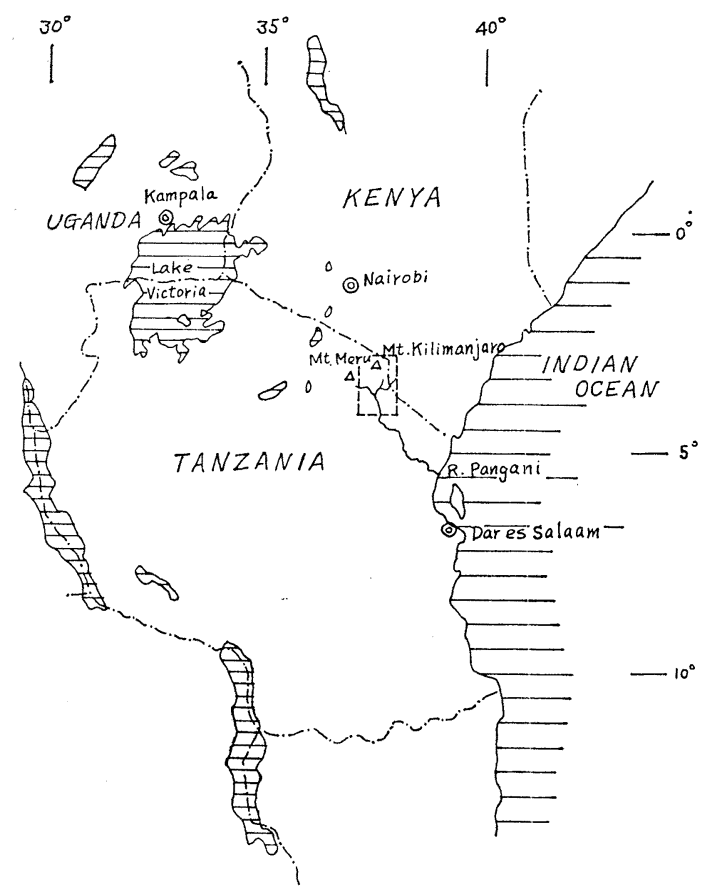

Fig.-1. Location Map of The Area.
家の皆様，タンザニア政府 Counterpart の皆様に厚く感 謝する次第である。

\section{2. 地形・地質}

地形: 本地域は Africa 大陸の最高峰 Kilimanjaro 山 の南楿に展開する広大な裾野平原で, 西は Lelatema Mts. (G.H. 1,600 m), 東は North Pare Mts. (G.H. $2,000 \mathrm{~m})$ のそれぞれ南北に伸びる山脈に囲まれ，南は Pangai 川の流域平野につらなる。Kilimanjaro 火山は中 心の Kibo (G.H. 5,895 m), 西の Shira (G.H. 4,005 m) そして東の Mawenzi (G.H. 5,148m) の三峰からなる成 層火山である。南麓は山頂から $30 \sim 50 \mathrm{~km}$ で平坦な裾 野平原になるが，丁度，Moshi と Himoを結ぶ National Road 付近に地形の変曲点があり, 以北は山腹急斜面, 以南は G.H. 700〜800 m にわたる緩斜面を経て沖積低 地に移過している。Kilimanjaro 山は赤道近くにありな がら高標高ゆえに頂上付近には万年雪をいただいてお り，氷河地形を示す終堆石が G.H. 3,000 m 付近まで認 められている。山腹斜面は地理学的に次のように大别さ れる。1）標高 $4.000 \mathrm{~m}$ 以上…万年雪で被われ，氷河堆 積物がみられる高山性荒地。2）標高 $3,000 \mathrm{~m} \sim 4,000 \mathrm{~m}$ …高山性草地。3）標高 2,000 3,000 m...雨量の多い密 林状の森林地帯。4）標高 1,200 2,000 m…温帯〜覀熱 带植物繁茂, 耕作地帯, 人口密度大。5）標高 750 1,200 $\mathrm{m}$ ‥半乾燥地帯定示す Steppe 地帯。そして 5）の下流 には Pangani 川上流ととの支流が作りだした広大な沖 積低地が拡がる。

Pangani 川流域平野の東を画す North Pare Mts. と 西を画す Lelatema Mts. は，それぞれ断層で平野に接 し，同平野は地溝性の構造盆地を形成している。

Kilimanjaro 山の山頂近くに源を発し，放射状に山腹 斜面を開折している溪谷を集めて Himo 川, Mua 川, Rau 川, Kikuletwa 川などの水系が発達し，それぞれ多。 くの支流を集めて南流し Pangani 川に合流する山麓斜面 が沖積低地に没するあたりには，火山山麓特有の湧水が 多くみられる。Moshi 近郊の Njoro 湧水, Prison の湧水 Miwaleni の大湧水などがそれである。なお, Kilimanjaro 山の西〜西南麓の Kenya 側には Chala 湖その他多くの 湧水が知られている。

地質：地質は North Pare Mts., Lelatema Mt. などを 構成するプレカンブリア紀の変成岩からなる基盤岩類, Kilimanjaro 山を構成する火山岩類及び Pangani 川流域

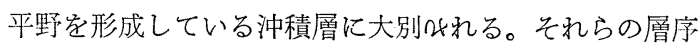
及び分布状況は Tb.-1, Fig.-2 のごとくである。 プレカンブリア紀の基盤岩類は, Mozanbiquian 
Orogenic belt の Usangaran System に属し，ザクロ石・ 石英・長石白粒岩, 硅石, ザク口石・硅線石白粒岩, 角 閃石片麻岩, 角閃石白粒岩, 黒雲母片麻岩及び結晶質石灰
岩等からなり (Geological Survey of TANZANIA, 1965), 既に述べたように North Pare Mts., Lelatema Mts. に 分布するほかに, Pangani 川沿いには調查地域南端の

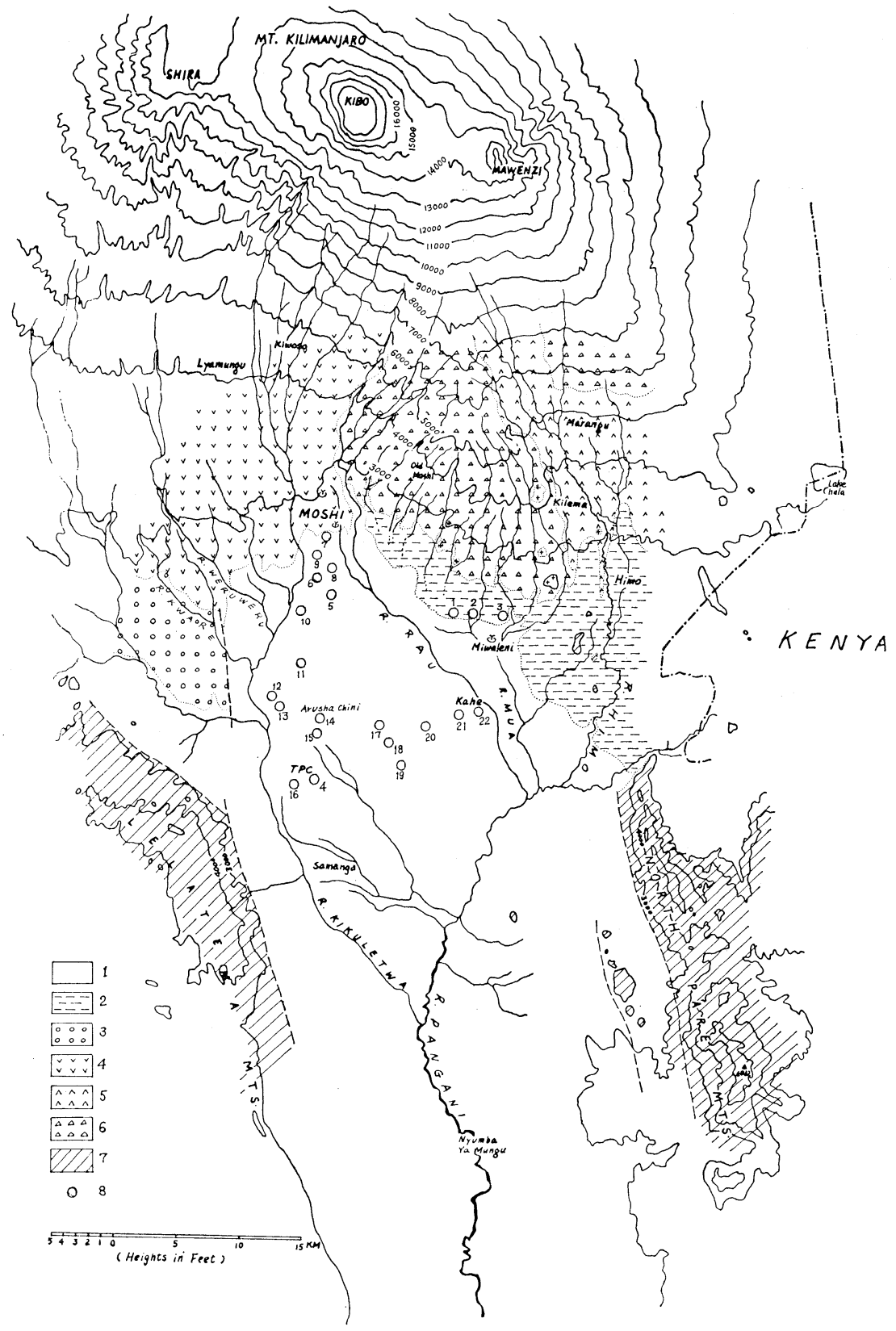

Fig.-2. Geological Map of The South Foot of Mt. Kilimanjaro
1: Alluvial deposits
2: Washout deposits
3: Lahar 4: Kibo Lava
5: Mawenzi lava
6: Pyroclastics
7: Precambrian system
8: Bore holes 
Tab.-1 Geological Formation

\begin{tabular}{|c|c|c|}
\hline Era & Formation & Facies \\
\hline \multirow{8}{*}{ Neogene } & & $\begin{array}{l}\text { Wash out deposits } \\
\text { (Loamy clay) }\end{array}$ \\
\hline & $\begin{array}{l}\text { Superficial deposits } \\
\text { (Alluvial deposits) }\end{array}$ & $\begin{array}{l}\text { Alternation of clay, } \\
\text { sand, gravel \& } \\
\text { limy deposits }\end{array}$ \\
\hline & & Sand \& gravel \\
\hline & & Alluvial fan deposits \\
\hline & \multirow{4}{*}{$\begin{array}{l}\text { Volcanis } \\
\text { (Kilimanjaro group) }\end{array}$} & $\begin{array}{l}\text { Parasitics } \\
\text { (Scoria \& ash) }\end{array}$ \\
\hline & & $\begin{array}{l}\text { Kibo } \\
\text { (Lahar, Porphyry) }\end{array}$ \\
\hline & & $\begin{array}{l}\text { Mawenzi } \\
\text { (Trachybasaltic lava, } \\
\text { Agglomerate) }\end{array}$ \\
\hline & & $\begin{array}{l}\text { Shira } \\
\text { (Trachybasalt, } \\
\text { Agglomerate) }\end{array}$ \\
\hline $\begin{array}{l}\text { Pre- } \\
\text { cambrian }\end{array}$ & $\begin{array}{l}\text { Usagaran of } \\
\text { Mozambiquian } \\
\text { Orogenic Belt }\end{array}$ & Gneiss, Granulite \\
\hline
\end{tabular}

Nymba Ya Mungu のダムサイトに露出している。

Kilimanjaro 火山の活動は，その開始期は必ずしも明 確でないが，Kenya 領の火山岩の放射性同位元素測定 結果が $13 \sim 15 \times 10^{6}$ Y.B.P. という值を得ていることな どから，中新〜鮮新世に初まり更新世から現世まで継続 されたと考元られている。現在は局所的に噴気孔を残し ているのみで，火山活動は体止期に入っているとされて いる。活動初期の地史は新期火山噴出物飞被われ明らか でないが，火山活動の中心は, Shira, Kibo, Mawenzi の 三峰を主体としている。そしてこれらの主峰とは別に無 数の小規模な寄生火山群が WNW-ESE 方向の配列它と って分布している。主峰のうちその活動が最も古いと思 われるのが Shira で，殆んど Kibo の火山岩類に被覆 されているが，主体は熔岩で火砕岩類を伴っている。 Mawenzi は Shira に次いで活動したもので，主に南側 〜東側に噴出物を流している。立武岩質熔岩を主体と し，同質凝兏角砅岩及び集塊岩を伴っている。最高峰の Kibo は最も新期の活動になるもので，主に北側と南側 に噴出物を流している。熔岩は長石の大きな斑晶の発達 した斑岩類で堅硬緻密で比較的浸食抵抗が強い。南麓の 都市 Moshi の市街地は，この Kibo の熔岩台地に乗っ ており熔岩の割れ目を透してきた水は，Njoro, Nsere, Shiri などの湧水となって地表に流出している。

Moshi の南西, Kahe の西方に Lahar と呼ばれる巨礫
にとさ堆積物が広く分布している。これは径 $10 \mathrm{~cm}$ 前後 の斑岩礫からなるもので，Kibo の主峰発達にともなっ て生成された大規模な Debris Flow の堆積物と考えられ ている。

Pangani 川上流域の沖積層は Kilimanjaro 火山噴出物 を被って分布する。堆積物は洗い出し堆積物，(Wash out deposits), 粘土，砂，碑及び石灰質粘土などから成 る。Wash out deposits は, 火山岩類の分布地域と沖積 堆積物の漸移帯に石死質堆積を被って分布するロ一ム質 粘土で火山岩の小碩（1～5 mu） を含む堆積物である。 その厚さは地表露頭の観察から $5 \sim 10 \mathrm{~m}$ 程度と考えら れる。洗い出し堆積物の下位には, 主として Miwaleni 湧水付近から南へ Kahe を中心石灰質粘土を含告粘 土，砂，碟からなる未固結の地層が広く分布している。 この地層の特徵は灰白色の石灰質粘土家層状に㣣みから

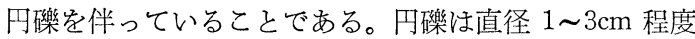
或はそれ以下の扁平な円碩が多く，殆んどが玄武岩及び 斑岩の Kilimanjaro 火山起源と推定される火山岩から構 成されている。石灰質粘土は灰白色定呈し，淡水性の貝 化石を含えでおり湖沼性堆積物と考えられる。これらの 沖積堆積物は, Miwaleni 湧泉周辺のほか, Rau 川下流, 川下流域など広範囲に観察され，さらに Arusha Chini その他におけるさく井資料からみると, Kahe〜Miwaleni 地域の地下に厚く広く分布していることが分かる。これ らの粘土・砂・䃯層の水平方向への連続性はよくなく, 地下深所では熔岩及び火砕岩類を挾在し Kilimanjaro 火 山噴出物と指交関係にあることが知られている。層厚は 既存の井户資料から判断すると，Arusha Chini 付近で 最大 $150 \mathrm{~m}$ 近くになるものと推定される (Fig. 3)。

この外，新期堆積物としては，火山斜面を開折する谷 に沿って小規模な段丘堆積物が，また山麓緩斜面付近に 直径 $10 \mathrm{~cm}$ 程度の円砅它主体とする扇状地性堆積物が認 められるが，ともに岩質はすべて火山岩類であり，谷に 沿うごく狭い範囲の分布にすぎない。

土壤：調査地は赤道に近く（南緯 $3 \sim 4^{\circ}$ ) 高温, 寊雨 の気候条件下にあり風化作用の激しい地域であり，表層 の土㙵は母岩の地質を反映して特徵ある分布を示してい る。Moshi〜 Himo 道路から北側の Kilimanjaro 山南斜 面は，玄武岩質熔岩あるいは同質火砕岩の風化した褐色 ～暗赤褐色のローム質土塞が厚く $(\max .5 \mathrm{~m})$ 分布し， 耕地として広く利用されている。道路から南側の洗い出 乙堆積物の分布地は，暗赤褐色の小礫混りの粘土が風化 分解した土塞となっている。一方 Miwaleni 湧水付近か ら南部の平地は石灰質堆積物の分布する地域であるた め，土塞も淡灰色～存色を呈し，全体として表層土塞も 


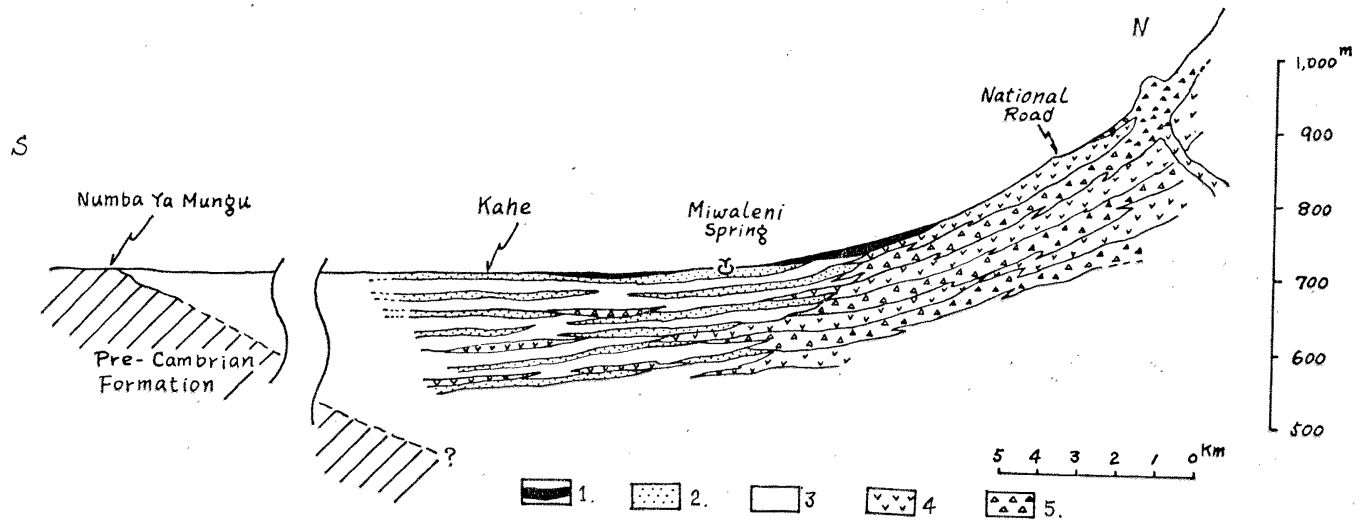

Fig.-3. Schematic Profile of The South Foot of Mt. Kilimanjaro.

1. Washout deposits, 2. Sand and Gravel, 3, Limy clayey deposits

4. Lava, 5. other Volcanics.

うすく，とくに鉄道 Kahe-Taveta 線より南側ほ植生に もその特徵を示している。プレカンブリア紀の地層の発 達する東部では，片麻岩が風化分解し Laterite 化した赤 褐色砂質粘土が広く分布するが，丘陵部でほ表土も薄く 大きな樹木もあ亦り認められない。

構造: この地域の地質構造它支配しているのは，南北 性のいわゆる Rift Valley 方向の構造である。Pare Mts. の西側と Lelatema Mts. の東側は，いずれも断層で平野 と接して中に摤安れる Pangani 川流域低地は, 地浔性の 凹地定形成し, Pangani Trough と呼ばれている(Geological Survey of Tanzania, 1965)。Pangani 川流域低地 の基盤と考えられるプレカンブリア紀の地層は，東西定 断層で切られ，北注 Kilimanjaro 火山体の地下深く沈み 込み，南は次第に浅くなり，Nunba Ya Mungu ダムサ イトで地表に露出する。従って, Pang 川上流低地は, 北方に深度を增す地濡性の盆地構造定示しているという ことができる。Kilimanjaro 火山は東西の方向性定もっ て西に延びている。本地域西方の Meru 火山はこの線上 にあり，さらに西方では Gregory Rift Valley と交叉す る。との東西系の構造は南北性の Rift Valley 密形成し た構造運動に関連したものと考えられている。

\section{3. 水文・気象}

河川：Kilimanjaro 山南麓の河川性，同山に源学発し放 射状に谷学開折して流下する Mua 川, Rau 川及び Kikuletwa 川などの水系に分類される。これらの河川は それぞれ多くの支流を集めて南下し合流して Pangeni 川 となり,さらに南下してインド洋へとそそぐ。
Mua 川は Mawezi 峰南斜面に源它発している。乾季 には Himo Moshi 道路沿いの Mua 川水系には表流水 は殆えど認められず，下流の鉄道橋付近になって初めて 流水をみるが，それは殆えど Miwaleni 湧水からくるも のと考元られる。Rau 川は Kilimanjaro 山の南斜面に源 娄発し, Moshi 市街地の東端を通りほぼ平野部の中央 を流下する。その本流は乾季でも表流水が認められる 名，支流は乾上ってしまう。本流は Hoshi の東部の湧 水を水源とする Njoro 川とMoshi の南で合流し, 鉄道 (Tanga Line) に沿って流下し, 流域には約 $5 \mathrm{~km}$ にわ たる森林地带を伴っている。しかしこの川の水は平野部 に技ける貴重なかんがい用水として利用され，Kahe の 南側では流量は殆えどなくなってしまう。Rau 川は Mua 川と共に Kahe の南約 $28 \mathrm{~km}$ の地点で Pangani 川 に合流し南流する。Kikuletwa 川はとの源流は地域西方 の Meru 山の南斜面に発するが，途中 Kilimanjajaro 山 の南西斜面の支流を合流させながら Moshi の南約 $40 \mathrm{~km}$ の所で Pangani 川と合流している。Kikuetwa 川水系の うち Kilimanjaro 山に源をもつ水系は, Kibo, Shira の 南斜面からくる Karanga 川, Weruweru 川及び Kikafu 川の三水系と Shira の南西〜西斜面に発する Kware 川, Sanya 川である。これらの水系のらち本地域に関係ある と考学られるのは前者であり, 乾季にも流水出ありいず れも Moshi の南ないし Kikafu Ya Chini 付近にが平 野に入って合流し，地域の西端を南流して Kikuletwa 川 に合流している。

これらの河川は, Rau 川及び Mua 川本流以外は殆え ど季節河川で乾期には表流水はない。Rau 川にしても 
山腹の森林地带の水を集めた表流水は極く一部で，大部 分は Njoro の满水が水源である。また Mua 川の水も上 流部は枯渴しており，流量のほとえどは Miwaleni 湧水 から得ている。Tab.-2 は各河川の流量を示したもので あり，その位置は Fig. -4 に示してある。Tab.-2 の資料
は観測時点が必ずしも一致しておらず同時性に欠ける が，4〜5 月の雨期に流量のピークがあり， 7〜10 月の 乾期に減水していることが分る。年平均流出率は, Rau 川 (IDC $3 \mathrm{~A}$ 地点) において降水量と流量を比較して 概算すると約 $12 \%$ 程度となる。

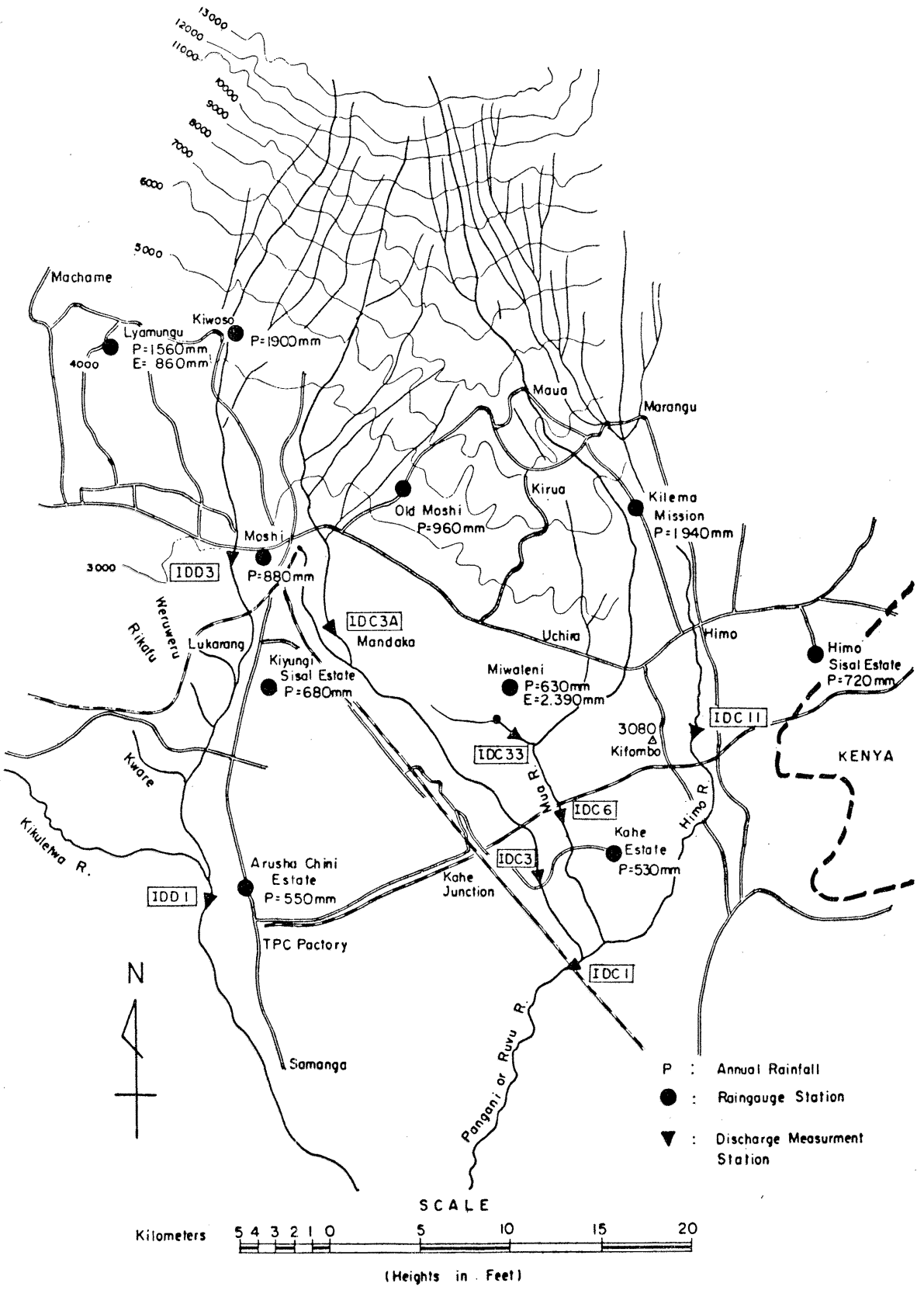

Fig.-4. Location Map of Raingauge and Discharge Measurment Stations 


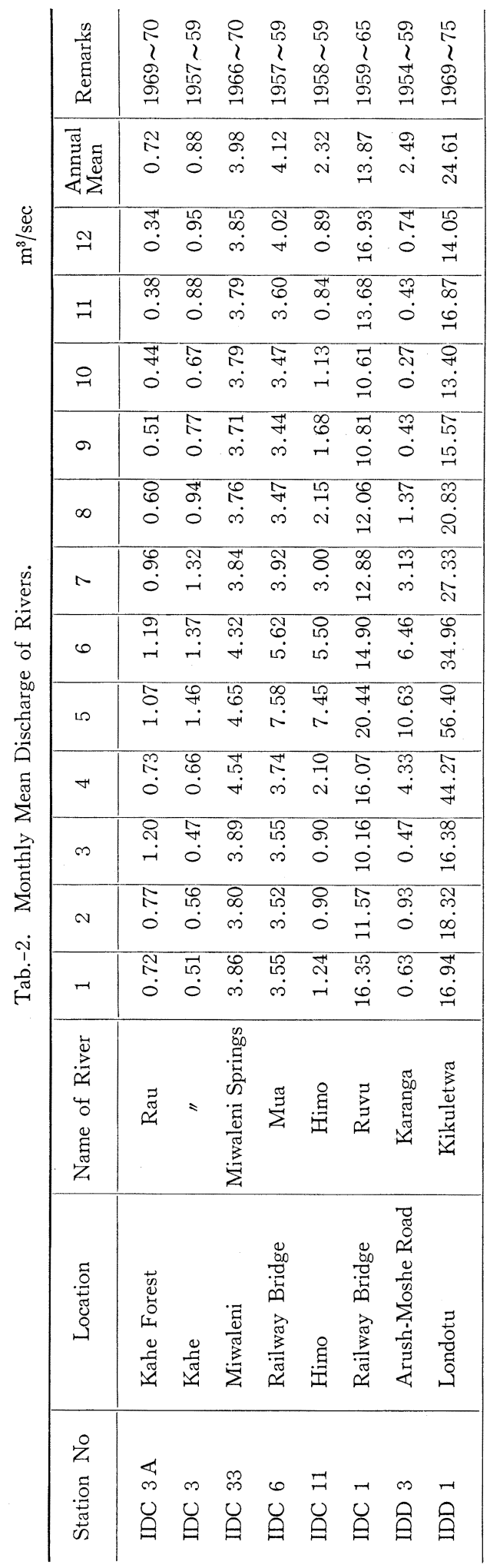

湧水: Kilimanjaro 山麓周辺には多くの湧水が分布し ているが，本地域では Miwaleni の大涌水群，Mohi 近 郊の Njoro 湧水打よび Moshi 市街 Prison 内の湧水な どがよく知られている。

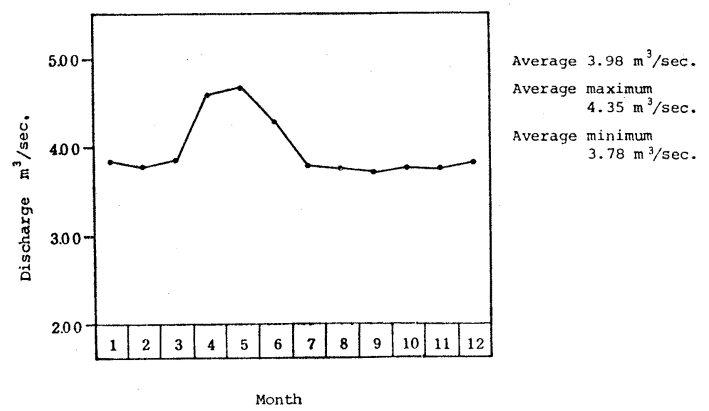

Fig.-5. Monthly Mean Discharge of Miwaleni Springs. (1966 1970 average)

これらの湧水は, いずれも Kilimanjaro 山の天水が火 砕岩の中に浸透し，一部は熔岩の割れ目を通して直接地 表に湧出 (Njoro) あるいは熔岩から沖積堆積層の粗粒部 を通って涌出 (Miwaleni) しているものである。Njoro, Prisonの湧水量については測定資料はないが，いずれも 数 $l / \mathrm{sec}$ 程度と推定される。Miwaleni 湧水群の湧出量に ついては, 継続的に観測されている。Fig.-5 は 1966 年 〜 1970 年の 5 年間の平均流出量を月毎に示したもので ある。この図からも分るように流量のピークは 4 6 月 に表われており，その他の季節は殆えど変らない流量を 示している。このことは 3〜5 月が大雨期で年雨量の約 $60 \%$ 以上がこの間に集中することから考えて，降雨は 約 1 力月おくれ地下水流出になることを示している。な お Miwaleni 湧水群の基底流量については, T.H. Mather (1964) 及び筆者らの収集資料によれば，年变化は多少 認められるものの，1958〜1970 年の観測データでは年 平均 $3.5 \mathrm{~m}^{3} / \mathrm{sec}$ であり，年变化をみても $3.0 \mathrm{~m}^{3} / \mathrm{sec}$ を 切ることはない。

降水: Kilimanjaro 南麓の季節は 3 5 月の大雨期, 11 12 月の小雨期， 7 9 月の乾期に大別される。大雨 期には年降水量の $60 \%$ 以上が降り，乾期にはほとんど 降雨がない。しかし乾期においても，中腹の森林帯など の高標高部では多少の降雨をみる。本地域及びその周辺 の雨量観測は, Moshi の Meteorologica Station, Lyamungu の農業研究所及び同 Miwaleni 分場等をはじめ, 学校，エステート等において行われており，それらのう ち資料の比較的揃っているもので地域に近いものを選え でその年降水量を示せば Tab.-3 の通りである。この表 
Tab.-3. Annual Precipitation at Selected Site in the South Foot of Mt. Kilimanjaro.

\begin{tabular}{lcc}
\hline \multicolumn{1}{c}{ Site } & Elevation & Precipitation \\
\hline Lyamungu & $1,250 \mathrm{~m}$ & $1,560 \mathrm{~mm}$ \\
Miwaleni branch & 725 & 630 \\
Moshi Met. Station & 870 & 880 \\
Kilewa Mission & 1,113 & 1,940 \\
Old Moshi School & 1,067 & 960 \\
Kiyungi Sisal Estate & 747 & 680 \\
Kahe Estate & 710 & 530 \\
Arusha Chini Estate & 716 & 550 \\
Himo Sisal Eestat & 792 & 720 \\
Kibosho Mission & 1,370 & 1,900 \\
\hline
\end{tabular}

から分るように，降水量は高標高部に集中し，山麓から 平野部にかけて急減する傾向にある。な抢，高標高部と 低標高部它代表する Lyamungu と Miwaleni の月別降 水量図安温度，蒸発量ととも Fig.-6 に动して抢く。

気熱・蒸発量: Lyamungu 及び Miwaleni における気 温と蒸発計蒸発量の観測資料は Fig.-6 に示されるごと くである。この図から分るように本地域は南半球に属す
るので気温の低くなるのは 6 8 月で，高いのは 1 \% 月 である。平地でも $700 \sim 800 \mathrm{~m}$ という高標高にあるた め, 気温の年較差は小さくむしろ 3 日較差の方が大き い。蒸発計蒸発量は, Lyamungu のそれは $860 \mathrm{~mm} /$ 年 と 降雨量の約 $50 \%$ 前後であるが, Miwaleni のとれは 2,390 $\mathrm{mm} /$ 年 と降雨量の実に 4 倍近い值を示している。蒸散 量の直接観測値はないが，山腹斜面と山麓平野部ではか なり違った值を示すものと推定される。即台 HimoMoshi 道路から北の斜面部は, バナナ・コーヒ一等の栽 培も行なわれ植生の状態が良いので, 蒸散量は蒸発計蒸 発量の $70 \%$ 程度と推定される。また, 道路から南の平 野部は, 年降水量も $500 \sim 600 \mathrm{~mm}$ と少なく気温も高い ので, 植生も踈でトゲのある植物が多く, 畑としても天 水它利用して雨期にトウモロコシ，豆類等を栽培してい るにすぎない。従って蒸散量は蒸発計蒸発量の約 $60 \%$ 程度と推定される。

\section{4. 水理地質}

帯水層：水理地質学的には片麻岩・白粒岩なぞからな るプレカンブリア紀の地層は, 本地域の不透水性基盤と 岁っている。この基盤の形態は既に述べたように，北に
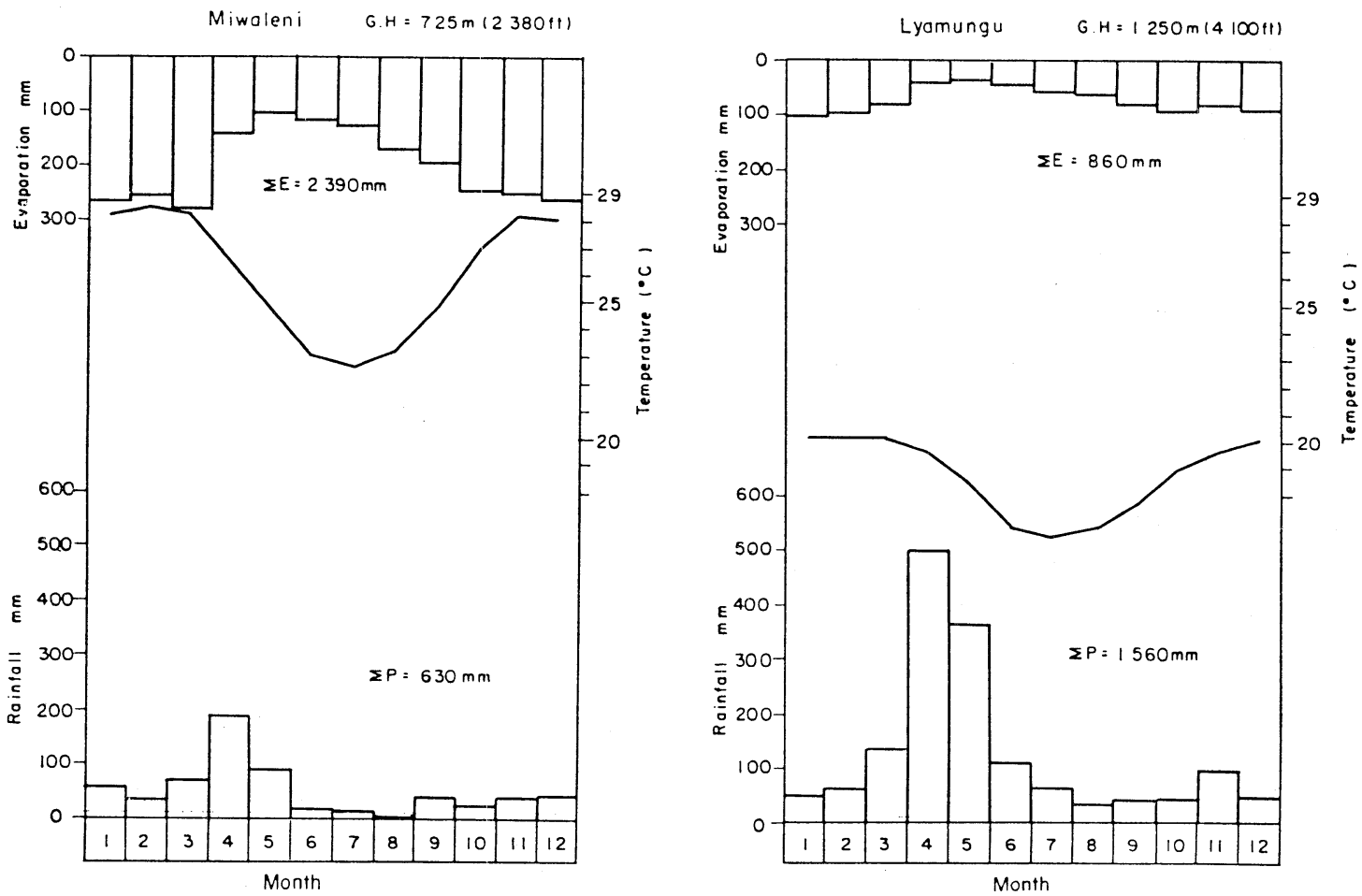

Fig.-6 Meteorological Data 
深い地溝性の盆地構造を示し，地下水理的に一つの地下 水盆它形成してい当。地下水盆の範围は，東と西は North Pare Mts. 及び Lelatema Mts. のそれぞれ西縁 と東縁で画され，南縁は Numba Ya Mungu 付近と考 えられる。盆地の北側では基盤は深く沈み込む構造を示 し，その北限は不明であるが，堆積盆地の北部は実質的 に半透水性の Kilimanjaro 火山噴出物で埋められており, 地下水包蔵帯の北限注実用的に Himo-Moshi 道路付近 と考党てよい。しかし，火山噴出物の分布地带は，割れ 目の発達やスコリヤ，自破砕熔岩などの粗粒部が透水带 を形成していることが容易に推定される。従って，地下 水盆北縁は带水層への地下水供給地带としての大きな役 割をむっているといえる。

堆積盆を埋積している堆積物は，粘土，砂，砂碩及び 火山岩類などの複雑な互層からなる新期堆積層である。 これらは熔岩家除き，いずれも未固結層で良好な帯水層 となっている。また熔岩類も割れ目や空陌にとみ，所に よっては帯水層となっている。

Fig.-7 は Miwaleni 溥水北部の東西方向の地質断面図 である。これは 3 本の既設井と 30 余点の電気探查の資 料によって作成したものである。図から分るように，表 層部は粘土質の細粒堆積物が多く，下位になるほど粗粒 堆積物が多くなるとともに，火山岩類の摤みが多くなる 傾向宗す。しかしながら，更に深部の岩相やプレカン ブリア紀層の基盤深度については，既設井資料からは筧 い知るととはできない。また，電気探査は最大探查深度 $200 \mathrm{~m}$ であったが, Miwaleni〜Kahe 地域では基盤と考
えられるような電気比抵抗值は得られていない。

Miwaleni 加ら Kahe, Arusha Chini にかけて Tab.-4 に示すような 22 の既設井が知られているが，それらは ほとえど深さ $100 \mathrm{~m}$ 以内で，収集し得た地質柱状図 (Fig.-8). からも分るように基盤に達しているものはな い。J.K. Whittingham (1963) は Arusha Chini の 400 フィートの井戸が基盤に達していると報告しているが， その井戸については柱状図は勿論, その位置さ光確認す ることができなかった。

地下水位, 揚水量, 水位降下量なぞ帯水層の水理学的 性質を知るための資料は, 実測した Miwaleni の 3 井及 び Kahe の 3 井以外は詳しい資料が公表されていない。 そくに T.P.C. (Tanzania Planting Company)の資料は, 企業秘密に属するらしく資料は得られない。しかしなが ら，聞きとりによる情報などから，全体的傾向として次 のようにまとめることができる。

地下水位は Miwaleni〜Kahe では $2 \sim 8 \mathrm{~m}$ と比較的深 く,南〜西部では部分的に 4 5 $\mathrm{m}$ というものもみられる が, 殆えど1〜2m と浅くなる。Miwaleni〜Kahe の水位 は带水層より高い位置にあり,明らかに被圧されている。

揚水量は, Miwaleni では 10 20 m の水位降下で比 湧出量にして 100 200 m³ $/ \mathrm{d} / \mathrm{m}$ 程度, Kahe で $10 \mathrm{~m}$ 前 後の水位降下で 200 $300 \mathrm{~m}^{3} / \mathrm{d} / \mathrm{m}$ の比湧出量它示してい る。Arusha Chini 加ら Moshi 東南の T.P.C の井戸に ついては正確な情報は分らないが，揚水実績からみると 4,000 5, $000 \mathrm{~m}^{3} / \mathrm{day}$ 之揚水量の多い井戸が多いことか ら, 比湧出量も南西へ下るに従って増加する傾向にある

\section{W}

E

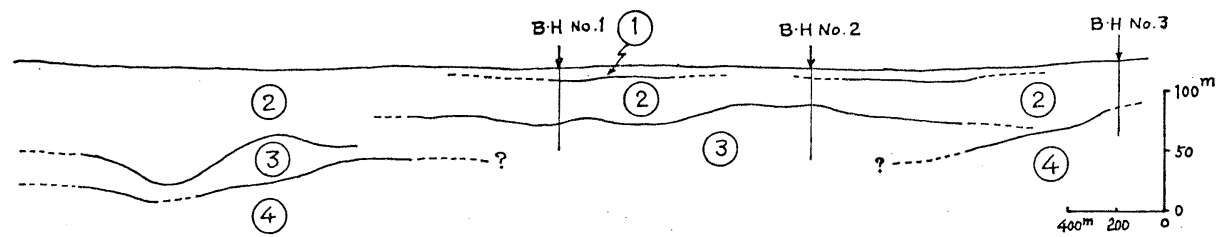

\begin{tabular}{|l|c|c|c|}
\hline Layer & $\begin{array}{c}\text { Electrical } \\
\text { Resistivity }\end{array}$ & Facies & $\begin{array}{c}\text { suitability } \\
\text { Aquifer }\end{array}$ \\
\hline (1) & $7 \sim 10^{\Omega m}$ & washout deposits & $\Delta$ \\
\hline$(2)$ & $3 \sim 8^{\Omega m}$ & $\begin{array}{l}\text { alternation of clay } \\
\text { sand, gravel and } \\
\text { limy deposits }\end{array}$ & 0 \\
\hline (3) & $30 \sim 90^{\Omega m}$ & $\begin{array}{l}\text { sand and gravel } \\
\text { Lava and other } \\
\text { volcanics }\end{array}$ & 0 \\
\hline (4) & $100 \sim 190^{\Omega m}$ & 0 \\
\hline
\end{tabular}

Fig.-7 Geological Section of upper Miwaleni Area

(After Electrical Sounding) 
Tab.-4. List of Existing Wells

\begin{tabular}{|c|c|c|c|c|c|c|}
\hline Location & Locality & Depth & Yield & $\begin{array}{l}\text { Amounts } \\
\text { of } \\
\text { Groundwater }\end{array}$ & $\begin{array}{l}\text { Columnar } \\
\text { Section }\end{array}$ & $\begin{array}{l}\text { Condition } \\
\text { of } \\
\text { Aquifer }\end{array}$ \\
\hline 1 & Miwaleni & $67.1 \mathrm{~m}$ & $104 \mathrm{~m}^{3} / \mathrm{h}$ & $832 \mathrm{~m}^{3} / \mathrm{d}$ & 0 & \\
\hline 2 & Miwaleni & 74.7 & 0 & 0 & 0 & \\
\hline 3 & Miwaleni & 59.5 & 0 & 0 & 0 & \\
\hline 4 & T.P.C. & 91.5 & & & 0 & \\
\hline 5 & T.P.C. & 91.5 & & & 0 & \\
\hline 6 & T.P.C. & 97.6 & 255 & 2,040 & 0 & \\
\hline 7 & T.P.C. & 91.5 & & & 0 & \\
\hline 8 & T.P.C. & 91.5 & 255 & 2,040 & 0 & \\
\hline 9 & T.P.C. & & 0 & 0 & 0 & \\
\hline 10 & T.P.C. & & 510 & 4,080 & $\times$ & Dry hole \\
\hline 11 & T.P.C. & & & & $x$ & \\
\hline 12 & T.P.C. & & 611 & 4,888 & $x$ & \\
\hline 13 & T.P.C. & & 765 & 6,120 & $x$ & \\
\hline 14 & T.P.C. & & 611 & 4,888 & $x$ & \\
\hline 15 & T.P.C. & & 510 & 4,080 & $x$ & \\
\hline 16 & T.P.C. & & 550 & 4,400 & $x$ & \\
\hline 17 & T.P.C. & & 510 & 4,080 & $x$ & \\
\hline 18 & T.P.C. & & 204 & 1,632 & $x$ & \\
\hline 19 & T.P.C. & & 357 & 2,856 & $x$ & \\
\hline 20 & Kahe & 54.9 & 173 & 1,384 & 0 & \\
\hline 21 & Kahe & 54.9 & 100 & 800 & 0 & \\
\hline 22 & Kahe & 61.0 & 100 & 800 & 0 & \\
\hline
\end{tabular}

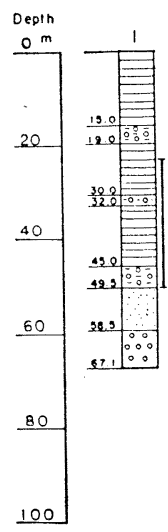

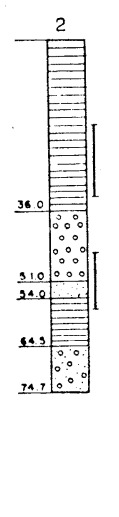

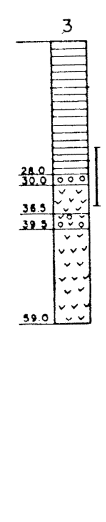

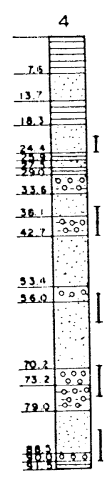
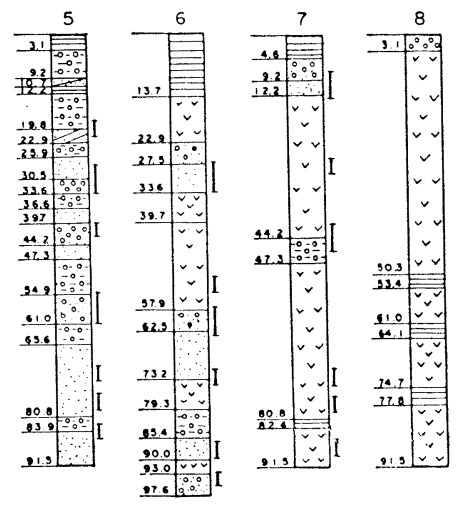

Fig.-8 Geological Colums of Existing Wells.
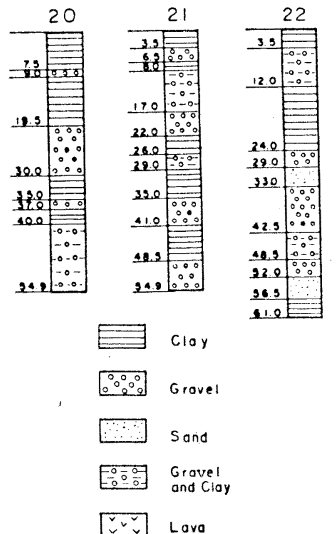

I water
と思われる。

Miwaleni の井戸で揚水試験を行なって, 帯水層常数を 求めたが，その結果透水量係数 $T=1.2 \sim 3.5 \times 10^{-3} \mathrm{~m}^{2} /$ sec であった。砂磎層を帯水層とする No. 1, No. 2 と 玄武岩質熔岩が砂碟層の下位に入ってくる No. 3 井を
比較すると，きしろ後者の方が $T$ は大きい。南の Kahe 〜Arusha Chini 地域の井戸については, 揚水試験の資 料はないが，揚水量と水位降下の知られている井戸につ いて試算すると， $T$ は $n \times 10^{-3} \mathrm{~m}^{2} / \mathrm{sec}$ のオーダーにな り, Miwaleni の带水層と殆えど変らないものと思われ 
る。なお，貯溜係数 $S$ については，観測井を設けない 試験だったため精度に問題はあるが，Miwaleni 1 号井で $S=8.16 \times 10^{-4}$ といら数字が得られている。

水質: 調查地域の河川水, 湧水及び井戸水約 20 力所 の水温, 電気伝導度及び $\mathrm{pH}$ 它測定した結果次のような ととが分かった。

河川水の水温は, 山腹部の谷の上流では $15^{\circ} \mathrm{C} \sim 16^{\circ} \mathrm{C}$ と低いが，平野部では $20^{\circ} \mathrm{C} \sim 22^{\circ} \mathrm{C}$ である。 Miwaleni の井戸水の水温は $22^{\circ} \mathrm{C} \sim 24^{\circ} \mathrm{C}$ で表流水よりもむしろ高 くなっている。湧水では Moshi 近郊の Kibo 熔岩から 湧出するものは $18^{\circ} \mathrm{C} \sim 19^{\circ} \mathrm{C}$ と低い令，砂碩層から湧出 する Miwaleni 湧水は $21^{\circ} \mathrm{C} \sim 23^{\circ} \mathrm{C}$ と高水温它示してい る。

電気伝導度は河川水ではやはり上流で非常に小さい值 $27 \sim 77 \mu \mho / \mathrm{cm}$ 定示すが，下流平野部では殆えど 200 以 上と高い值を示している。地下水の電気伝導度は, Miwleni の井戸で $380 \mu \mho / \mathrm{cm}$ という值を示しており, 他 の井戸については今回測定出来なかったが，T.P.C.の 井戸でかつて測定された值として 522 或いは 110 という 数值がある。全体としてかなりバラッキがあるものの， 河川水に比べて高い值を示するのと思われる。湧水の電 気伝導度は, Moshi 近郊のものは 100 150 $\mu \% / \mathrm{cm}$ と小 さいが, Miwaleni 湓水のそれは 220 400でとくに石灰 質堆積層の部分办ら湧出していると思われる水は 928 $\mu \mho / \mathrm{cm}$ と大きな值を示している。

P.H. は井戸水，旉水について測定したが，7.0 8.0 の弱アルカリ性を呈し，とくに石灰質堆積層からの湧水 は 8.0 に近い值を示している。その他の項目についての 水質分析は未だ実施されていないが，T.P.C.の 2 井の 試料についてかつて行われた分析結果によると， $\mathrm{Ca}^{++}$,

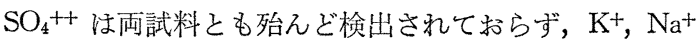
がそれぞれ 23〜13 ppm，65 45 ppm 検出されている。

以上，水質については分析項目，試料数も少く充分な 解析はできないが，河川水，溥水，井戸水とそれぞれの 賦存環境を反映した特徵的な数值を示していることが分 る。

水収支：これまで述べてきたように，この地域の主要 な地下水涵養源は, 水理地質構造から, 比較的降雨量が 多く蒸発散の少い Kilimanjaro 山南斜面の降水と考兄ら れる。平野部に入ると年雨量も $650 \mathrm{~mm}$ 程度と少く, 蒸 発量は雨量をはるかに上回るようになり，降水による直 接の地下水補給は望めない。表流水は Mua 川では乾期 には上流からの流入はなく，Rau川は僅かの表流水が認 められる分，両水もむしろ下流の湧水から涵養されてい る。最も流量の豊富な Kikuletwa 川は, 堆積盆地の西
縁に沿って流れて和り，地下水盆内一の伏没涵養量は多 くは期待できない。また，盆地の東西を画すプレカンブ リア紀の不透水性基盤岩からなる山地は, 降水量も少く 流域も小さいので地下水の涵養源としての役割は殆んど 果していないものと思われる。

Kilimanjaro 山は成層火山で多くの寄生火山灾伴うが, 山体は熔岩流の外集塊岩や火砕岩によって構成されてい る。熔岩や火碎岩のうちでも比較的古期の風化の進えで いるところでは浸透量も多いと考兄られる。一方，Kibo 熔岩流分布地域では气の割机目を通しての地下水流出が 考光られる。また，山体の中腹には雨量の多い幅 $10 \mathrm{~km}$ にも及ぶ森林地帯があり, 地下水涵養源としての機能它 充分備光ている。従って本地域の地下水は, 艺の殆えど が Kilimanjaro 山南麓斜面森林地带及びその下方平野部 までの中間地帯を涵養源としていると考えられる。

今, 地下水流出量它次のような簡単な収支式で概算し てみることとする。

$$
Q=\{P-(D+E)\} \times A
$$

$$
\begin{aligned}
& \text { ここに， } Q \text { : 地下流出量 }\left(\mathrm{m}^{3} / \mathrm{y}\right) \\
& P: \quad \text { 降水量 }(\mathrm{mm}) \\
& D: \quad \text { 流出量 }(\mathrm{mm}) \\
& E: \text { 蒸発散量 }(\mathrm{mm}) \\
& A \text { ：涵養区域面積 }\left(\mathrm{km}^{2}\right)
\end{aligned}
$$

この式で降水量 $P$ は, 前述の資料から森林地帯で, 2,000 mm/year, 中間地帯で 1,500 mm/year とする。流 出量 $D$ は，流出係数を前述資料から森林地带で 0.10 , 中間地帯で 0.15 とすると, 森林地带の, $D=200 \mathrm{~mm} /$ year, 中間地带の $D=225 \mathrm{~mm} / \mathrm{year}$ となる。同じく蒸発 計蒸発量索森林地带 $700 \mathrm{~mm} / \mathrm{year}$, 中間地带 $860 \mathrm{~mm} /$ year とし，との $70 \%$ 蒸発散量 $E$ と考元ると森林地 帯で $490 \mathrm{~mm} / \mathrm{year}$, 中間地帯で $600 \mathrm{~mm} /$ year となる。涵 養面積は Rau 川, Mua 川流域に限って森林地带を 72 $\mathrm{km}^{2}$, 中間地带を $245 \mathrm{~km}^{2}$ とし上記の数值を用いて地下 水流出量 $Q$ 它試算すると約 2.6 億 $\mathrm{m}^{3} / \mathrm{year}$ となる。

しかしながら Kibo 熔岩類の下位には Shira その他古 期の火山噴出物の分布が推定され，より広い流域からの 地下水流出が考光られる。さらに，Kikafu 川上流域に は火砕岩類で代表される透水性の地層の分布地域があ り，乙の流域加らの涵養量を概算すると約 4,000 万 $\mathrm{m}^{3}$ ほどになる。従って，本地域の地下水涵養量は Rau川， Mua 川流域及びその他の流域からのものを考慮すれば， 総計約 3 億 $\mathrm{m}^{3} / \mathrm{year}$ 程度と試算される。

地下水盆からの主な流出, Miwaleni 湧水及び T.P.C. などに扔ける井戸からの揚水と考光られる。 Miwaleni 湧水からの流出量は, 年平均最小 $3.78 \mathrm{~m}^{3} / \mathrm{sec}$ と考元ら 
Amount of Recharge
Amount of Discharge
Amount of Object of

Future Development

(Approximately)

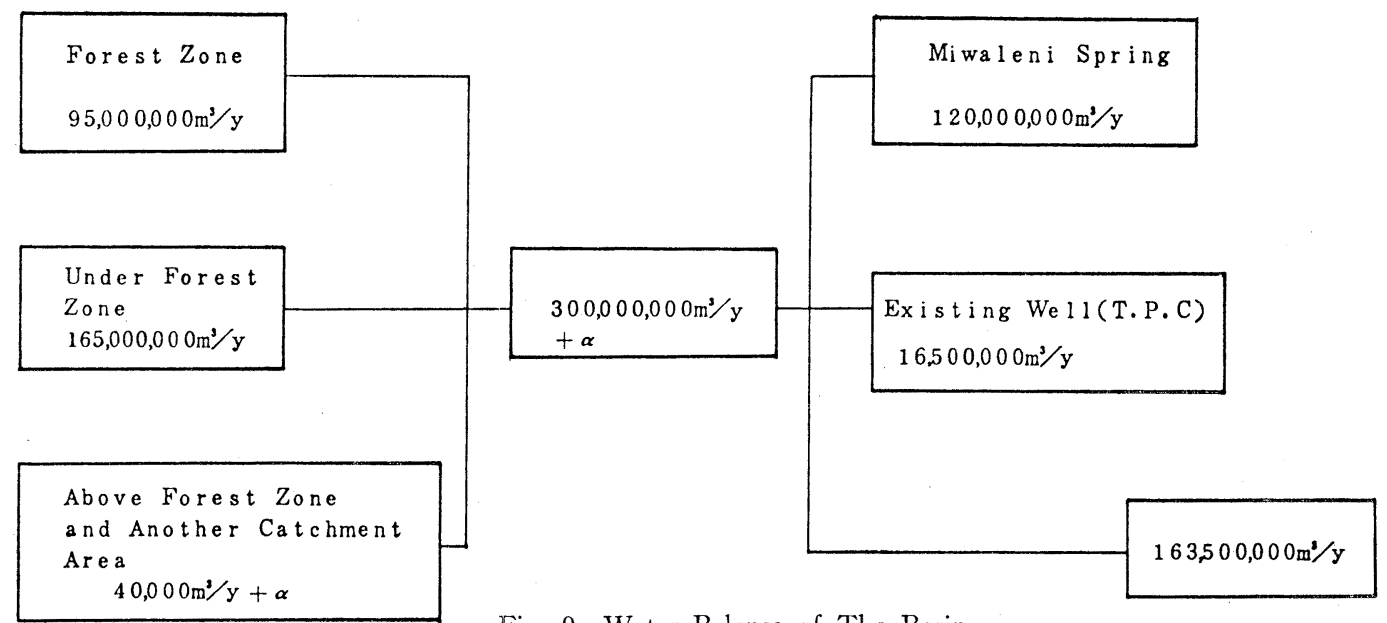

Fig.-9 Water Balance of The Basin

れ，また地下水揚水量は年平均約 $45,000 \mathrm{~m}^{3} /$ day 程度々 推定される。この地域の地下水収支をまとめると Fig.9 に示すようになる。

この図から分るように, 総涵養量は活よそ 3 億 $\mathrm{m}^{3}$ year, 流出量は約 1 億数千万 $\mathrm{m}^{3} /$ year と推定されるので, 涵養量の約 $1 / 2$ 分将来の地下水開発の対像となる。しか しながら，採水施設や水理学的な制約のため，とのすべ てを採水することは技術的に不可能で，実際の将来可能 採水量は, この量の $1 / 2$ 以下, 約 5,000 万 $\mathrm{m}^{3} /$ year 程度 と考えるべきであろう。

なお，これらの試算はあくまでも概算であり，かつ森 林地帯の降水量，蒸発量などに関する実測値がなく推定 值によっているので，今後さらに資料を増やして再検討 する必要があろう。

\section{References}

1) A.M. Quennel (1956): Summary of the Geology of Tanganyika,

Part I: Introduction and Stratigraphy

2) J.F. Harris (1956): Summary of the Geology of Tangayika,

Part IV: Economic Geology

3) F.M. Coster (1960): Underground Water in TANGANYIKA Printed by the Government Printer, Dar es Salaam, 1960

4) W. Halcraw and Partners (1962): Report on the Development of the Pangani River Basin, Oct. 1962 (Consultants Company)

5) J.K. Whittingham (1963): Geological and Geo- physical Investgations for Water Supply in Moshi Area

6) T.H. Mather (1964): Kahe Irrigation Scheme, Miwaleni Springs Discharge Analysis (Appendix E), Dec. 1964

7) J.C. Ramsay (1965): Kilimanjaro-Sources of Water Supplies, Tanganyika Notes and Records, Mar. 1965

The Journal of the Tanganyika Scoeity

8) K. Simura (1965): Electric Sounding Method, Printed by Shokodo (in Japanese)

9) Geological Survey of Tanzania (1965): Geological Map of "DALUNI", Sheet No. 91 \& 110, compiled and published by Geological Survey Division, Dodoma, 1965

10) Geological Survey of Tanzaia (1965): Geological Map of "SAME", Sheet No. 89, compiled and published by Geological Survey Division, Dodoma, 1965

11) Geological Survey of Tanzania (1963): Geological Map of "MNAZI (KALIMAE)", Sheet No. 90, compiled and published by Geological Survey Division, Dodoma, 1963

12) Geological Survey of Tanzania (1962): Geological Map of “NORTH PARE", Sheet No. 73, compiled and published by Geological Survey Division, Dodoma, 1962

13) Geological Survey of Tanzania (1965): Explanatory Notes on the Geological Map of "KILIMANJARO" Geological Survey Division of Tanzania, 1965

14) I. Matsuzawa (1966): A Study on the Formation of the African Rift Valley, Dec. 1966 
The Journal of Earth Sciences, Nagoya Univ., Vol. 14

15) P. Schroeter (1966): Hydrogeological Investigation of the Miwaleni Spring, Near Moshi, Northern Tanzania (Vol III, Section 3), Oct.-Dec., 1966

16) East African Academy (1966): Research Services in East Africa

17) E. Felfadi (1967): Summary of Subsurface Investigations for Kahe-Miwaleni Area, Report of F.A.O., June, 1967

18) S. Yamamoto (1968): Pumping Test and Well Management, Printed by Shokodo (in Japanese)

19) K. Suwa (1969): Metamorphic Rocks of the North Pare Mountains, Tanzania, The Journal of Earth Science, Nagoya Univ., Vol. 17 (Special Volume) 97-106

20) Nagoya Univ., Department of Earth Science (1969): Nagoya University African Rift valley Expedition 1968 Report, Dec. 1969

21) Davis \& Sorensen (1969): Handbook of Applied Hydraulics, Printed by McGraw-Hill Book Company
22) Balasha \& Jalon Consultants and Engineers Ltd. (1969): Master plan of Development and Utilization of Ground water in Tanzania, Oct. 1969

23) R.W. Girdler (Ed.)(1972): East Africa Rifts-Developments in Geotectonics-Vol. 7, 179 p, (Elsevier, Amsterdam-London-New-York, 1972)

24) The Society fer the Study of Water Balance (1973): The Ground Water Resources, Printed by Kyoritsu-Shuppan K.K. (in Japanese)

25) Overseas Technical Cooperation Agency (1974): The Survey Report for Agricultural Cooperation Project in Kilimanjaro Region, Tanzania, Feb. 1974

26) K. Suwa (Ed.)(1975): First Preliminary Report Of African Studies, Association for African Studies, Nagoya Uuiv., Mar. 1975

27) Atlas of Tanzania: Hydrology, Mean Annual Rainfall, Rainfall Probability, Physical, Geology, Soils, Regions and Districts, Potential Land Use and Others

28) Kokin-Shoin: The Climate of the World, Vol. II, Africa (in Japanese) 